Милош Д. Ђурић

Електротехнички факултет

Универзитет у Београду
069.01:316.7

069.02:39]:004

https://doi.org/10.18485/melissa.2017.16.1.ch11

\title{
НЕКИ АСПЕКТИ ДИСКУРСА ДИГИТАЛНИХ МУЗЕЈА ДИГИТАЛНЕ УМЕТНОСТИ
}

\begin{abstract}
Сажетак
Ово истраживање је део ширег интердисциплинарног поља проучавања дискурса, или специфичније, дискурса музеја дигиталне уметности, које истражује различите аспекте језичких израза који се манифестују у текстовима музеја дигиталне уметности. Уводни део моје презентације дефинише истраживачку перспективу. Почевши од једног случаја дискурса музеја дигиталне уметности, разматрам неке централне и статистички релевантне лексичке јединице повезујући их, путем илустрације, са дискурсним праксама музеја дигиталне уметности. Други део мог истраживања је, како општи, тако и специфичан по својој оријентацији. Овај део бави се питањем репрезентативности корпуса и описује неке стандардне алате коришћене у рачунарској анализи текста. Фокус се онда помера на разматрање резултата добијених применом рачунарске анализе текста на корпус дискурса музеја дигиталне уметности. Моја истраживачка намера заснована је на полазној претпоставци да високо фреквентне пуне речи овог дискурсног типа могу да представљају идеје суштинске за дискурс музеја дигиталне уметности. У ову сврху, рачунарска анализа текста се примењује на одабране веб странице које садрже релевантне делове дискурса који се разматрају. У трећем делу се предлаже интердисциплинарни приступ теорији дискурса музеја дигиталне уметности и указује на неке могуће правце за даља проучавања дискурса музеја дигиталне уметности путем рачунарске анализе текста. Коначно, последњи део рада даје сажетак мојих налаза.
\end{abstract}

Кључне речи: дискурс музеја дигиталне уметности, енглески језик, пуне речи, сложенице, подаци засновани на корпусу, рачунарска анализа текста (РАТ) и алати рачунарске анализе текста (АРАТ).

\section{0. Уводне напомене}

Као што то истичу извесни аутори, деведесете године XX века биле су погодне за процват и развој брзине дигиталних медија, а 
поједини то називају и „дигиталном револуцијом“ (Paul 2008: 7). У овом раду ћу се фокусирати на један специфичан дискурс, а то је дискурс дигиталних музеја дигиталне уметности. Према литератури, виртуелни музеји јесу електронски, интерактивни музеји у којима се посетиоци могу кретати из једне просторије у другу, бирајући одређени експонат из просторије са циљем да га подробније анализирају (Miller et al. 1992: 183).

Према литератури, да би се схватили елементи који данас сачињавају музеј, неопходно је да се заузме истраживачки приступ који идентификује функције стварног музеја и његовог главног преображаја у вези са развојем технологије, са посебним освртом на дигитална окружења (Panciroli, Russo \& Macauda 2017: 1). Поред тога, према литератури, дигитални музеји се посматрају као платформе, а дигитални кустоси као шампиони у добу друштвених медија (Proctor 2010: 35-43). У оквиру дигиталне уметности, која је битна за овај рад, истичу се, између осталог, концепти, попут проширене стварности, вештачког живота, аутономних катактера, сајберпростора, хипертекста, хипермедија, телеприсуства, телероботике (Paul 2008: 247).

Ослањајући се на рачунарску анализу текста, у овом раду ћу анализирати језичке облике из дискурсне перспективе музеја дигиталне уметности. Језичка анализа подразумева анализу засебних текстуалних узорака и анализу текстуалног корпуса који је ексцепиран са интернет страница дигиталних музеја дигиталне уметности. Текстови су подвргнути рачунарској анализи са циљем да се обезбеде статистички докази о дискурсним праксама дигиталних музеја дигиталне уметности.

Одабир управо вирутелних музеја који се налазе на интернету управно је условљен и тиме што се у XXI веку интернет мрежа сагледава и као метафора друштвеног живота као флуида. Интернет мрежа обухвата мноштво људи, програма, машина, текстова и слика у којој се ови субјекти и објекти мешају чинећи нове хибридне форме. Управо ове хибридне форме генеришу непланиране и насумично формиране обрасце.

И дигитални музеји, по угледу на велике мултинационалне корпорације, посматрају интернет као исплативе начине за побољшање комуникације између група, а самим тим, интернет 
презентације могу да побољшају ефикасност ове врсте комуникације на компјутеру.

Како бих прецизније и егзактније сагледао дискурсне праксе дигиталних музеја и музеја дигиталне уметности, користио сам се алатима из области рачунарске анализе текста. Статистичка структура језика може да укаже на доминантне колокације, доминантне идеје у дискурсу. Овакву статистичку слику можемо помоћу бројања различитих језичких јединица у оквиру узорка који испитујемо. Према релевантној литератури, у оквиру сваког нивоа језичке структуре могуће је избројати јављање различитих језичких јединица, а онда добијене фреквенције појављивања могу да се доведу у узајамни однос у циљу увиђања статистичких правилности употребе ових језичких јединица (Kristal 1996: 86).

У првом делу рада дајем кратак опис корпуса и вршим делимитацију извесних кључних појмова, а затим у другом делу наводим листе фреквенције појављивања и описујем алате за рачунарску анализу текста. У наредном делу рада, пажња је усмерена на са̂м дискурс веб страница дигиталних музеја дигиталне уметности, као и на рачунарску анализу текста.

Наредни део рада садржи конкретну примену рачунарске анализе текста на дискурс дигиталних музеја дигиталне уметности употребом конкретних алата и применом неметричког мултидимензионалног скалирања. У последњем делу се износе завршне напомене у вези са спроведеним истраживањем.

\section{0. Опис корпуса и делимитација кључних појмова}

У овом делу рада дајем кратак опис корпуса. Прецизније, мој корпус чине веб странице дигиталних музеја са којих сам ексцерпирао стаистички репрезентативан узорак текста, а чији је детаљан опис дат у одељку Напомена о изворима примера. Али да би се стекао утисак, макар у статистичку адекватност и репрезентативност, наводим само податке везане за број страна, речи, пасуса и редова. Разлог за управо ове параметре и за овај редослед јесте практичне 
природе. Наиме, сви документи, односно текстуални материјали са веб сајтова, конвертовани су у Microsoft Word 2007 document format, те су стога на овај начин и квантификовани.

Kорпус Digital Art Museum (DAM) обухвата 67 страна, 36618 речи, 26 пасуса, 3154 редова. Корпус The Digital Museum of Digital Art. A Virtual Institution (DiMoDA) конвертован је у два засебна документа, од којих први обухвата 18 страна, 9064 речи, 140 параграфа, 727 редова, а други документ обухвата 9 страна, 999 речи, 6 параграфа и 106 редова. Корпус Museum of Computer Art (MOCA) садржи 2 стране, 398 речи, 17 параграфа, 50 редова. Корпус LaTURBO AVEDON садржи 10 страна, 1699 речи, 46 пасуса, 152 реда. Корпус Lucas Museum of Narrative Art - Digital Art обухвата 9 страна, 581 реч, 29 пасуса, 98 редова, а корпус Dunking Bird Galleries обухвата 23 стране, 12127 речи, 135 пасуса, 949 редова.

У оквиру презентација, користећи различите алате за рачунарску анализу текста, фокусирали смо се на пуне речи, зато што сматрамо да су оне носиоци значења у оквиру дискурса дигиталне уметности. Сем тога, у овој врсти дискурса, пуне речи имају стабилно значење и прилагођавају се дискурсном окружењу у коме се налазе, што је у овом случају дискурс дигиталних музеја дигиталне уметности. Први корак је посматрање изолованих пуних речи, међутим, пошто нам реченична семантика, али и дискурсна семантика понекада дају примере лексичких јединица које испољавају двосмисленост, вишезначност, онда смо посматрали и конструкције у ширим склоповима, попут синтагми, колокација, реченица, параграфа. Пошто кључне речи најбоље описују процесе одређене области, узете су у обзир и кључне речи које су такође анализиране.

Пуне речи се у литератури одређују као једна од две постулиране главне класе речи у језику (поред празних речи). Према лингвистичкој литератури, пуне речи садрже лексичко значење, за разлику од празних речи, које имају чисто граматичку улогу (Kristal 1988: 214). Дакле, празне речи се одређују као речи које немају лексичко значење, а чија је једина функција да изразе граматичке односе (Kristal 1988: 196). И други аутори подржавају ову дистинкцију ослањајући се на семантички критеријум, односно критеријум значења, па кажу да је пуна 
реч она чије је значење лексичко, пре него граматичко (Matthews 2005: 138), а празна реч јесте реч која се сагледава као јединица чије је значење пре граматичко, него лексичко (Matthews 2005: 113). Пуне речи се, у литератури, називају још и садржинске речи које се одређују као речи које поседују независно, односно, речничко значење (Kristal 1996: 429), а исти аутор у цитираном раду одређује празну реч као реч без значења која изражава неки граматички однос, а овакву реч назива још и потпорница (Kristal 1996: 428).

У наредном делу рада, погледаћемо укратко начин и алате помоћу којих је извршена анализа.

\section{1. Листе фреквенције појављивања и алати за рачунарску анализу текста}

Анализа текстуалног корпуса може се побољшати коришћењем рачунарске анализе текста. Ова врста рачунарске анализе користи се у разноврсним пољима, а занимљива је употреба рачунарске анализе текста у области проучавања језичких варијација (Biber 1995). Управо цитирани лингвиста, Даглас Бајбер, користио је у својој студији и рачунарски моделоване параметре и за утврђивање стилистичких својстава и варијација између текстова и жанрова.

Поред своје очигледне брзине у обради података, рачунари нуде и сасвим нове квалитете студијама заснованим на изучавању корпуса. Употребом рачунара добија се и једна доследна и стабилна анализа. У овом раду користим термине рачунарска анализа текста (РАТ) и алати рачунарске анализе текста (АРАТ) прилично лабаво, без теоријске привржености било којој школи или моделу. РАТ се односи на сам поступак који сам користио, а у оквиру мојих истраживања АРАТ обухвата алате помоћу којих сам добио и анализирао листе фреквенција употреба термина, конкорданце, алфабетски устројене листе и листе базичних нумеричких параметара.

Листе фреквенције појављивања лексичких јединица показују апсолутне и релативне учесталости свих врста различитих облика речи у мом текстуалном корпусу. Сем тога, ове листе су битне и за укључивање у сложеније мултидимензионалне анализе. Према ли- 
тератури, факторска анализа је примарни статистички алат за мултидимензионални приступ текстуалним варијацијама (Biber 1995: 79).

Од алата за рачунарску анализу текста користио сам иницијално Xerox POS tagger, Word Counter, а затим и Tool KH Coder. Првопоменути алат разврстава може да се практично користи у анализи припрадности врсти речи анализираних јединица у тексту. Други алат се може користити у израдама листа према разлитичим параметрима, а највећу примену у мом истраживању имао је алат КH Coder, који је послужио за добијање велике већине података који су анализирани. У наредном делу рада саопштићу резултате мерења спроведених наведеним алатима за рачунарску анализу текста.

\section{2. Дискурс веб страница дигиталних музеја и рачунарска анализа текста}

У овом делу рада, погледаћемо пар анализираних листа речи, односно фреквенција појављивања у корпус. Најпре сам анализирао корпус DAM. На основу рачунарске анализе утврђено је да је најфреквентнија лексичка јединица art која се јавља чак на 336 места. Затим највећи број токена има именица artist, која се јавња 215 пута. Од придева је најфреквентнији придев nеw који се јавља 78 пута. Доминантне именице су program (јавља се 55 пута), process и world (обе се јављају 52 пута).

\begin{tabular}{|l|l|c|}
\hline \multicolumn{1}{|c|}{$\begin{array}{r}\text { Лексичке } \\
\text { јединице }\end{array}$} & \multicolumn{1}{|c|}{ Врста речи } & $\begin{array}{c}\text { Фреквенција } \\
\text { појављивања }\end{array}$ \\
\hline art & Noun & 336 \\
\hline artist & Noun & 215 \\
\hline -RSB- & ProperNoun & 157 \\
\hline work & Noun & 149 \\
\hline -LSB- & ProperNoun & 144 \\
\hline use & Verb & 135 \\
\hline image & Noun & 130 \\
\hline Art & ProperNoun & 106 \\
\hline make & Verb & 98 \\
\hline machine & Noun & 91 \\
\hline new & Adj & 78 \\
\hline object & Noun & 74 \\
\hline form & Noun & 71 \\
\hline
\end{tabular}




\begin{tabular}{|l|l|l|}
\hline mathematical & Adj & 70 \\
\hline artistic & Adj & 64 \\
\hline mathematics & Noun & 62 \\
\hline visual & Adj & 57 \\
\hline program & Noun & 55 \\
\hline process & Noun & 52 \\
\hline world & Noun & 52 \\
\hline Cohen & ProperNoun & 51 \\
\hline digital & Adj & 51 \\
\hline human & Adj & 50 \\
\hline graphic & Noun & 48 \\
\hline
\end{tabular}

Табела 1.2.1. Табела генерисана помоћу алата $K X$ кодер за корпус $D A M$.

Занимљиво једа поредпоменутих фреквентних лексичких јединица, доминирају и ајтеми, попут mathematics (јавља се 62 пута), program (јавља ce 55 пута), machine (јавља се 91 пут) и object (јавља се 74 пута). Оваква статистичка заступљеност говори о релевантности ових термина у дискурсним праксама дигиталних музеја дигиталне уметности.

Како бих утврдио дискурсне праксе у оквиру корпуса $D A M$, посматрао сам доминантне колокације, сложенице, или уопштеније групе (енг. clusters) ${ }^{1}$. Најфреквентније су следеће групе или скупине: digital art museum, computer graphics, work of art, art object, modern art, digital art, digital art museum, mathematical art, computer artists, computer art pioneers, digital computer, visual computer, modern art movements, early computer art, computer artist, electronic art. Kao што видимо из наведене листе, у скупинама доминирају семантичке јединице које садрже уметност и уметнике, као и врсте и подврсте дигиталне уметности, пошо су у питању дискурсне праксе овако једне специфичне врсте виртуелних музеја.

Анализираћемо и корпус DiMoDA. Најпре ћемо погледати најфреквентније лексичке јединице у овом корпусу. За разли-

1 Овде прилично лабаво користим термин „група“, без икаквихтеоријских залагања, као концептуални кишобран који обухвата именичке следове, сложенице, комплексне номинале, па и колокације. Поред тога, у мом раду се термину група придаје значење које му даје Дејвид Кристал у преводу Бориса Хлебеца и Ивана Клајна, а који користећи халидејевску терминологију у ову категорију сврставају: именичке групе, глаголске и адвербијалне групе, уз напомену да је „термин синтагма еквивалентан [...] у већини других приступа (Kristal 1988: 90). 
ку од претходног корпуса, овај ћемо илустровати табелама, како би се стекао утисак у могућности алата за рачунарску анализу текста. Погледаћемо табеларно учесталост појављивања статистички релевантних лексичких јединица.

\begin{tabular}{|l|l|c|}
\hline $\begin{array}{c}\text { Лексичке } \\
\text { јединице }\end{array}$ & Врста речи & $\begin{array}{c}\text { Фреквенција } \\
\text { појављивања }\end{array}$ \\
\hline DiMoDA & ProperNoun & 113 \\
\hline virtual & Adj & 87 \\
\hline art & Noun & 75 \\
\hline Digital & ProperNoun & 74 \\
\hline artist & Noun & 65 \\
\hline museum & Noun & 59 \\
\hline work & Noun & 59 \\
\hline ART & ProperNoun & 53 \\
\hline New & ProperNoun & 50 \\
\hline Alfredo & ProperNoun & 46 \\
\hline digital & Adj & 45 \\
\hline MUSEUM & ProperNoun & 42 \\
\hline Salazar-Caro & ProperNoun & 41 \\
\hline institution & Noun & 41 \\
\hline exhibition & Noun & 37 \\
\hline William & ProperNoun & 34 \\
\hline reality & Noun & 32 \\
\hline Robertson & ProperNoun & 31 \\
\hline kind & Noun & 30 \\
\hline space & Noun & 29 \\
\hline work & Verb & 29 \\
\hline way & Noun & 26 \\
\hline Media & ProperNoun & \\
\hline new & Adj & 26 \\
\hline
\end{tabular}

Табела 1.2.2. Табела генерисана помоћу алата $K X$ кодер за корпус DiMoDA. 
Према овом алату, најфреквентнија је јединица управо лексема која доминира у овом корпусу - DiMoDA, која се јавља 113 пута. Затим су ту virtual, art и digital ${ }^{2}$. Занимљиво је што је веома фрекевентна семантичка јединица MUSEUM (јавља се на 42 места у корпусу) вероватно, услед своје ортографске реализације (написана великим словима), третирана као властита именица ${ }^{3}$.

Групе или скупине које су доминантне у корпусу DiMoDA jecy следеће: digital art, Dimoda digital museum of digital art, digital museum of digital art, alfredo salazar-caro, new media, virtual reality, William Robertson, contemporary digital art, courtesy of dimoda, virtual institution, new museum, kind permission, image courtesy of dimoda, new media artists, new media artist, virtual museum, virtual space, contemporary art, Claudia Hart, image (c) alfredo salazar-caro, digital museum, the digital museum of digital art, art object, digital media. У дискурсним праксама овог музеја и овог корпуса доминирају сложенице, тј. скупине које садрже разноврсне подскупове дигиталних уметника, затим скупине којима се одређују музеји, који могу бити виртуелни музеји, дигитални музеји, али и дигитални музеји дигиталне уметности.

Погледаћемо и фреквенцију најучесталијих лексичких јединица у корпусу MOCA.

\begin{tabular}{|l|l|c|}
\hline \multicolumn{1}{|c|}{$\begin{array}{c}\text { Лексичке } \\
\text { јединице }\end{array}$} & Врста речи & $\begin{array}{c}\text { Фреквенција } \\
\text { појављивања }\end{array}$ \\
\hline MOCA & ProperNoun & 10 \\
\hline art & Noun & 6 \\
\hline artist & Noun & 6 \\
\hline Don & ProperNoun & 4 \\
\hline digital & Adj & 4 \\
\hline Museum & ProperNoun & 3 \\
\hline New & ProperNoun & 3 \\
\hline
\end{tabular}

2 Занимљиво је да овај алат услед ортографије третира јединицу Digital као властиту именицу (енг. proper noun) само зато што је написана великим словом. Ја нисам намерно интервенисао у овим случајевима, како бих оставио оригиналну анализу коришћених алата. Сем тога, узгред, интересантно је приметити да дигитални уметници и дигитални кустоси користе врло често велико слово за придев Digital y оквиру лексичке јединице Digital art.

3 Видети фуснноте бр. 2 и 3 за детаљније објашњење. 


\begin{tabular}{|l|l|l|}
\hline exhibit & Noun & 3 \\
\hline view & Verb & 3 \\
\hline work & Noun & 3 \\
\hline Archer & ProperNoun & 2 \\
\hline Art & ProperNoun & 2 \\
\hline Soper & ProperNoun & 2 \\
\hline Steve & ProperNoun & 2 \\
\hline Web & ProperNoun & 2 \\
\hline York & ProperNoun & 2 \\
\hline best & Adj & 2 \\
\hline don@moca.virtual.museum & Noun & 2 \\
\hline experience & Noun & 2 \\
\hline museum & Noun & 2 \\
\hline site & Noun & 2 \\
\hline skill & Noun & 2 \\
\hline status & Noun & 2 \\
\hline visit & Verb & 2 \\
\hline
\end{tabular}

Табела 1.2.3. Табела генерисана помоћу алата $K X$ кодер за корпус MOCA.

Као што се и види из табеле 1.2.3. најфреквентнија јединица је управо назив музеја (МOCA) који се јавља 10 пута. Затим именице art и artist (по 6 пута), онда придев digital, а затим museum ${ }^{4}$. Пошто је овај корпус знатно мањи, онда је и фреквенција појављивања доминантних лексичких јединица осетно мања у односу на друге корпусе, што, свакако не умањује њихов значај и релевантност у овом корпусу. У корпусу МОСА доминантне групе, односно скупине су: digital art, museum of computer art, Moca museum of computer art, computer artists Don Archer, respected computer art museums, drawn art, high art, rendered art, world-class digital artists, digital artist, museum domain management association, many talented artists, moca co-founder, moca curator, moca logo, moca site, top-level domain, current exhibit, exhibit catalogs, personal webpage, webpage experience.

Видимо да у скупинама доминирају следови који садрже конституент тоса као неку врсту сигнала припадности управо дискурсној

Види фусноте бр. 2 и 3 за објашњење третирања ове лексичке јединице као властите именице. 
пракси овог дигиталног музеја. Па тако, видимо да постоји Моса кустос, Моса суоснивач, Моса лого, сајт, итд. Поред тога, фреквентне и доминантне скупине су још и сотрuter museum, затим computer artist и museum of computer art. Дакле, видимо да фигурирају лексичке јединице које садрже конституент computer, указујући на различите видове рачунарске уметности, што спада у доминантну дискурсну праксу у оквиру корпуса MOCA.

Погледаћемо статистичку слику за корпус LaTurbo Avedon.

\begin{tabular}{|c|c|c|}
\hline $\begin{array}{l}\text { Лексичке } \\
\text { јединице }\end{array}$ & Врста речи & $\begin{array}{l}\text { Фреквенција } \\
\text { појављивања }\end{array}$ \\
\hline AVEDON & ProperNoun & 21 \\
\hline space & Noun & 17 \\
\hline LATURBO & ProperNoun & 16 \\
\hline work & Noun & 16 \\
\hline virtual & Adj & 10 \\
\hline New & ProperNoun & 8 \\
\hline artist & Noun & 8 \\
\hline live & Verb & 8 \\
\hline avatar & Noun & 7 \\
\hline consider & Verb & 7 \\
\hline experience & Noun & 7 \\
\hline media & Noun & 7 \\
\hline paraspace & Noun & 7 \\
\hline production & Noun & 7 \\
\hline sculpture & Noun & 7 \\
\hline surface & Noun & 6 \\
\hline Sculpt & ProperNoun & 5 \\
\hline authorship & Noun & 5 \\
\hline identity & Noun & 5 \\
\hline object & Noun & 5 \\
\hline parasubject & Noun & 5 \\
\hline polygon & Noun & 5 \\
\hline social & Adj & 5 \\
\hline term & Noun & 5 \\
\hline
\end{tabular}

Табела 1.2.4. Табела генерисана помоћу алата $K X$ кодер за корпус LaTurbo Avedon. 
Доминантне лексичке јединице су AVEDON (јавља се 16 пута) LATURBO (налази се на 21 месту у тексту корпуса). Занимљиво је и статистички, појављивање лексема virtual (јавља се 10 пута) и avatar (јавља се 7 пута). Управо ове две лексеме учествују у грађењу идентитета уметника ЛаТурбо Аведона, који у овом својеврсном дигиталном музеју у коме су дела дигиталне уметности, експлицитно наводи да је он заправо аватар и уметник који настаје у виртуелном простору, па стога није ни зачуђујуће што се по фреквенцији ове лексеме и истичу у овом узорку.

Доминантне групе у корпусу LaTURBO Avedon јесу следеће: LaTurbo Avedon, Avedon's work, new sculpt, virtual space, media experience, transfer gallery, production of space, nonphysical identity, laturbo avedon's works, mode of production, projected works, Duke university press, white cube gallery, virtual authorship, raw material, abstracted parasubject, LaTurbo Avedon's creations, LaTurbo Avedon gamespace, LaTurbo Avedon's physical anonymity, Donna Haraway, explosion of forms, Facebook timeline.

Као што видимо, фреквенција појављивања скупина која садрже име овог виртуелног уметника и аватара (LaTurbo Avedon) је висока, као и скупине које садрже теоретичарку и ауторку киборга Дону Харавеј.

Анализираћемо статистику у корпусу LMNADA - Lucas Museum of Narrative Art - Digital Art.

\begin{tabular}{|l|l|c|}
\hline \multicolumn{1}{|c|}{$\begin{array}{r}\text { Лексичке } \\
\text { јединице }\end{array}$} & Врста речи & $\begin{array}{c}\text { Фреквенција } \\
\text { појављивања }\end{array}$ \\
\hline Digital & ProperNoun & 18 \\
\hline Art & ProperNoun & 16 \\
\hline art & Noun & 14 \\
\hline digital & Adj & 10 \\
\hline artist & Noun & 9 \\
\hline medium & Noun & 6 \\
\hline technology & Noun & 6 \\
\hline Lucas & ProperNoun & 5 \\
\hline form & Noun & 5 \\
\hline use & Verb & 5 \\
\hline Museum & ProperNoun & 4 \\
\hline collection & Noun & 3 \\
\hline narrative & Adj & 3 \\
\hline painting & Noun & 3 \\
\hline
\end{tabular}


ТРАНСКУЛТУРАЛНОСТ И БИБЛИОТЕКЕ

\begin{tabular}{|l|l|l|}
\hline story & Noun & 3 \\
\hline technological & Adj & 3 \\
\hline tell & Verb & 3 \\
\hline work & Noun & 3 \\
\hline Categories & ProperNoun & 2 \\
\hline Fine & ProperNoun & 2 \\
\hline George & ProperNoun & 2 \\
\hline Illustration & ProperNoun & 2 \\
\hline Industrial & ProperNoun & 2 \\
\hline John & ProperNoun & 2 \\
\hline
\end{tabular}

Табела 1.2.5. Табела генерисана помоћу алата $K X$ кодер за корпус LMNADA Lucas Museum of Narrative Art - Digital Art.

Као што видимо из табеле генерисане помоћу овог рачунарског алата, најфреквентнија је лексичка јединица Digital, која се третира као властита именица 5 . Затим следи лексичка јединица Art, а онда и семантичке јединице digital, artist и medium које приближавају дискурсне праксе ове врсте дискурса. Затим смо генерисали доминантне скупине из овог корпуса, а према овим алатима, то су: digital art, digital medium, narrative art forms, digital art medium, traditional art forms, narrative art, digital fine art, history of digital art, computer art, digital art plays, digital technology, fine art, medium artists, Lucas museum of narrative art, early pioneers of digital art, children's art, comic art, technological barriers, digital architecture, digital cinema, digital illustration, digital media, digital sculpture, forms of art today, digital technology developments, museum of middle eastern art, (C) copyright lucas museum of narrative art, industrial light, radical digital revolution, world's first computer-generated art, computer technology, cutting-edge digital works, spellbinding photorealistic digital images.

Дакле, видимо да у овим скупинама доминира дигитална уметност, затим рачунарска уметност, затим сам назив музеја наративне уметности (одељак за дигиталну уметност), затим су ту скупине које садрже пионире дигиталне уметности, а дискурсне праксе корпуса LMNADA опчаране су фотореалистичним дигиталним сликама (што илустративно показује скупина spellbinding photorealistic digital images).

5 Видети напомене у фуснотама бр. 2 и 3. 
Погледаћемо и шести корпус, односно, DBG - Dunking Bird Galleries.

\begin{tabular}{|l|l|c|}
\hline $\begin{array}{l}\text { Лексичке } \\
\text { јединице }\end{array}$ & Врста речи & $\begin{array}{l}\text { Фреквенција } \\
\text { појављивања }\end{array}$ \\
\hline art & Noun & 164 \\
\hline work & Noun & 92 \\
\hline digital & Adj & 84 \\
\hline artist & Noun & 83 \\
\hline Art & ProperNoun & 54 \\
\hline create & Verb & 54 \\
\hline make & Verb & 52 \\
\hline image & Noun & 41 \\
\hline tool & Noun & 41 \\
\hline Digital & ProperNoun & 38 \\
\hline new & Adj & 38 \\
\hline print & Noun & 37 \\
\hline time & Noun & 36 \\
\hline use & Verb & 28 \\
\hline thing & Noun & 25 \\
\hline color & Noun & 24 \\
\hline canvas & Noun & 23 \\
\hline way & Noun & 23 \\
\hline world & Noun & 23 \\
\hline ink & Noun & 22 \\
\hline begin & Verb & 21 \\
\hline just & Adv & 20 \\
\hline paint & Noun & 20 \\
\hline place & Noun & \\
\hline & & 20 \\
\hline
\end{tabular}

Табела 1.2.6. Табела генерисана помоћу алата $K X$ кодер за корпус DBG - Dunking Bird Galleries.

Доминантне скупине у овом корпусу су: digital art, digital artist, fine art, machine art, video art, fine arts, digital artists, digital tools, work of art, original art, digital arts, art history, reproducible art, visual art, digital work, digital art prints, world of fine art, digital print, traditional art, art work, digital media, digital manifesto, digital works, art piece, original work, art world, world of art, notion of art, reproducable art, un- 
precedented art, original digital art, art historians, manifesto of digital art, digital art making, digital artwork, digital art printing, digital art technology, web art, ink jet, ink longevity, knowledge of art, digital machine, art of synthesis, other art, digital art fare, digital art fit, digital art shows, digital art visit, surmounted digital art, old art.

Дакле, као што видимо, према резултатима, може се уочити да су у овим скупинама најфреквентније оне које садрже лексему art (нпр. web art, manifesto of digital art) или пак оне које садрже digital art. Дискурсне праксе овог музеја нам преносе поруку о синтези уметности, сајму дигиталне уметности, посетама дигиталној уметности. Такође се јавља група машинска уметност (тj. machine art), али и видео уметност, примењена уметност, дакле, различити подскупови скупа уметност.

Погледали смо по пар примера из анализираних корпуса како бисмо илустровали дискурсне праксе дигиталних музеја дигиталне уметности у зависности од фреквенције појављивања извесних лексичких јединица, као и доминантне лексичке скупине (било да су у питању колокације, синтагме, сложенице, низови). Видели смо да ове лексичке скупине најшеће преносе поруку о синтези уметности, затим илуструју распон различитих термина који обхватају уметност, а који се могу сматрати градијентним. Такође, примећено је да придев digital колоцира са статистички релевантним бројем лексичких јединица творећи једно ново ткање у дискурсном универзуму дигиталних музеја дигиталне уметности.

У наредном делу погледаћемо и могућност употребе и 2Д и ЗД неметричког мултидимензионално скалирање у оквиру анализираних корпуса.

\section{0. Примена рачунарске анализе текста на дискурс дигиталних музеја дигиталне уметности - мултидимензионално скалирање}

У претходном делу, видели смо оно што би се окарактерисало као „класична“ статистичка анализа, која обраћа пажњу искључиво на фреквенцију појављивања, а онда се изводе закључци из тога. Ипак, оно што је релевантније за моју анализу, а и што је циљ овог рада 
(осветљавање дискурсних пракси дигиталних музеја дигиталне уметности) јесу рафиниранији и комплекснији односи који се могу наћи у конкретном језичком материјалу. У анализирању ових односа може помоћи мултидимензионално скалирање, које завређује сопствени део рада.

Помоћу мултидимензионалног скалирања изналазе се комбинације или групе речи које имају сличан образац појављивања. Помоћу овог алата израчунава се компрезентност ${ }^{6}$ речи без обзира на фреквенцију појављивања. У алатима сам одабрао Kruskal, а то је неметричко мултидимензионално скалирање, које може имати дводимензионално и тродимензионално решење. У првом корпусу, ради илустрације, погледаћемо и тродимензионално решење, али ћемо после углавном наводити дводимензионално, због једноставнијег праћења.

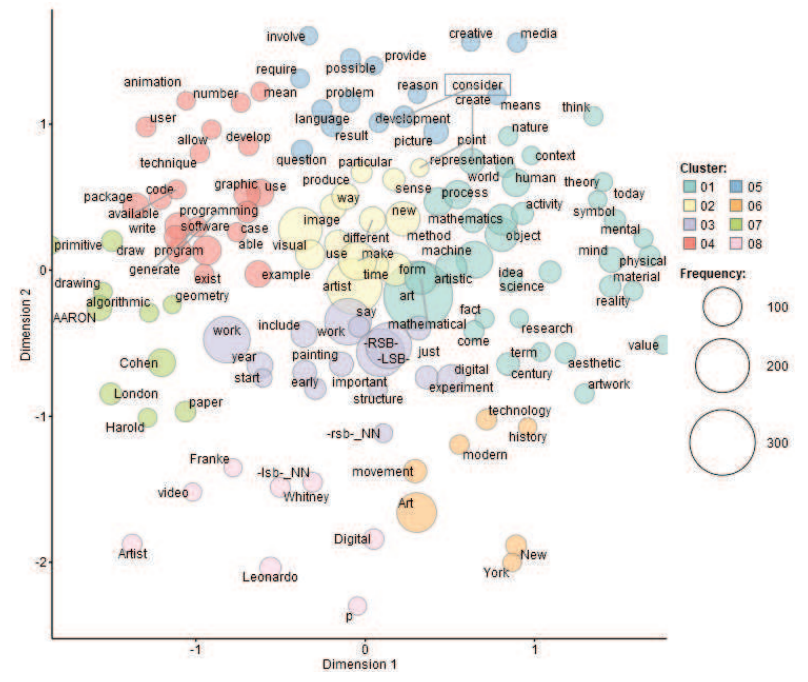

Слика 2.0.1. Дводимензионално решење за неметричко мултидимензионално скалирање (2Д Крускал) за корпус DAM.

На слици 2.0.1. видимо дводимензионално решење за неме-

6 Термин компрезентан први су превели лингвисти Иван Клајн и Борис Хлебец са енглеског на српски језик. Као преводиоци Кристаловог Енциклопедијског речника модерне лингвистике они су разрешавали, поред овог, и многе друге терминолошке проблеме, па су и пионири у ковању нових термина у српском (тадашњем српскохрватском) језику. „Компрезентан“ (енг. co-оccurring), према литератури, означава дозвољену синтагматску комбинацију јединица, према граматичким и лексичким правилима језика (Kristal 1988: 123). 
тричко мултидимензионално скалирање (у даљем тексту 2Д Крускал). Као што се види удаљеност између појединачних лексичких јединица је лака за праћење иако се јавља мноштво комбинација у овим скупинама. На пример, са лексемом programming колоцирају software, code и package, па се онда генеришу скупине: programming software, programming code, programming package.

Погледаћемо и тродимензионално решење, али, чини нам се да није прегледно у тој мери као дводимензионално, можда због величине корпуса.

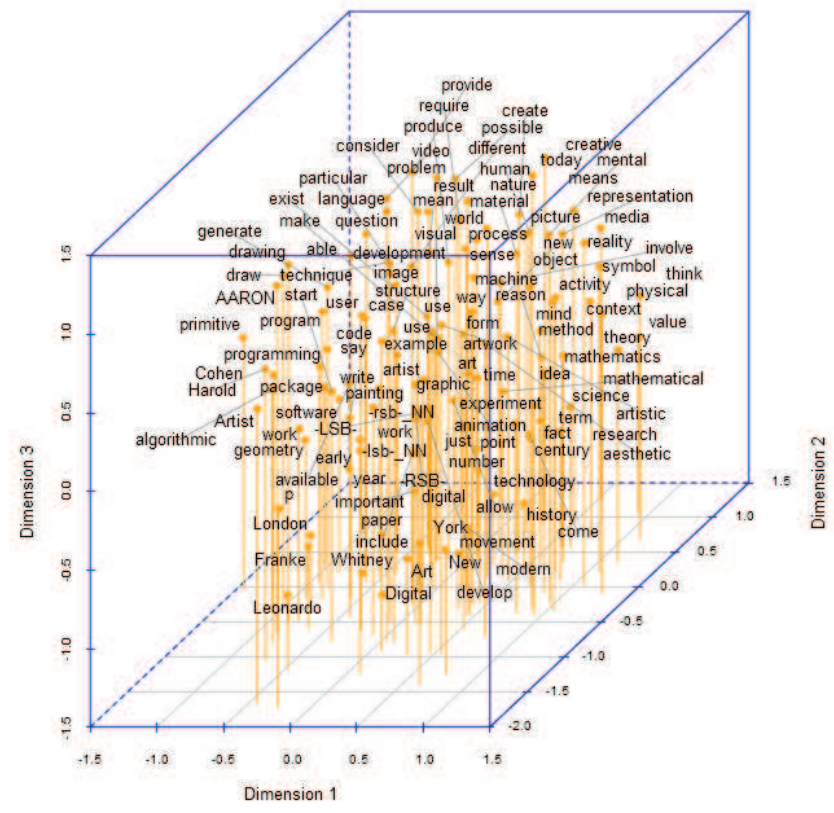

Слика 2.0.2. Тродимензионално решење за неметричко мултидимензионално скалирање (ЗД Крускал) за корпус DAM.

Као што се види на слици 2.0.2., ово је тродимензионално решење за неметричко мултидимензионално скалирање (у даљем тексту: ЗД Крускал). Међутим, иако је ово ЗД решење често и прегледније и практичније, чини се да у овом случају, можда услед величине корпуса, оно не приказује могућности комбиновања скупина довољно прегледно.

Погледаћемо стање у корпусу DiMoDA. 


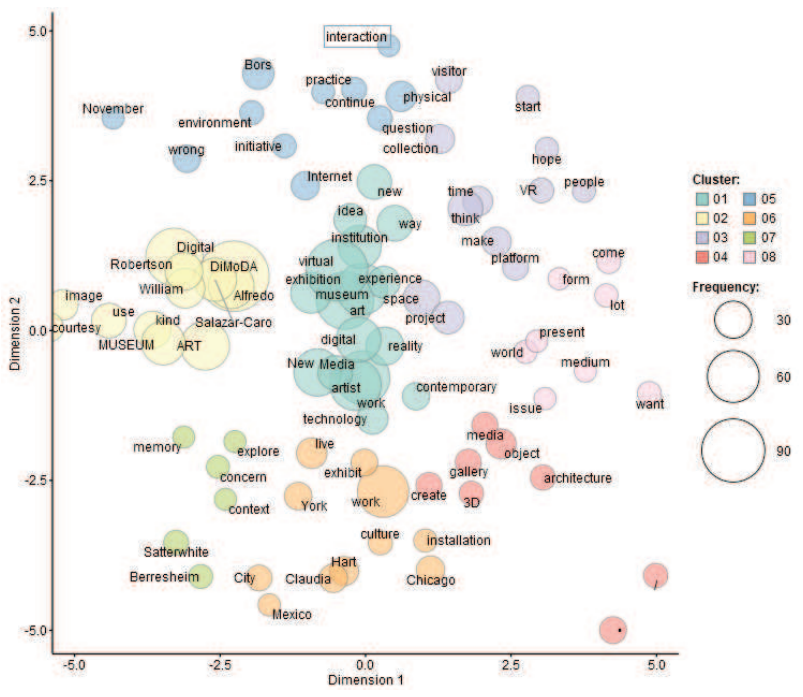

Слика 2.0.3. 2Д Крускал за корпус DiMoDA.

Као што се види на слици 2.0.3. семантичка јединица VR колоцира са јединицама people, platform, time, итд. А придев virtual генерише скупине virtual museum, virtual exhibition, virtual experience.

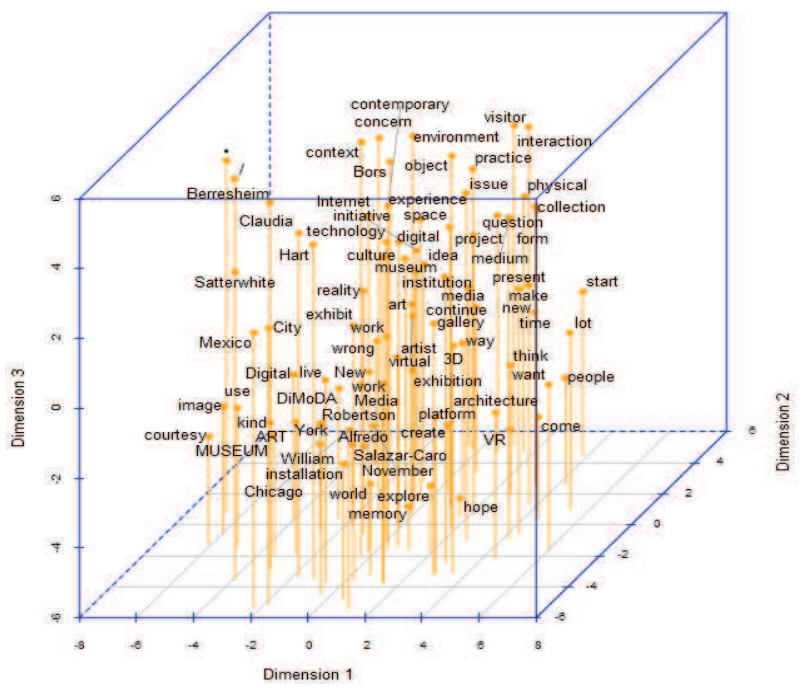

Слика 2.0.4. ЗД Крускал за корпус DiMoDA. 
Слика 2.0.4. илуструjе ЗД Крускал за корпус DiMoDA, а видимо потенцијалне скупине које се могу генерисати комбинацијом лексичких јединица које су близу једна друге.

Видели смо да су ови алати корисни (у извесној мери) приликом статистичке анализе специфичног дискурса, односно, шире посматрано, приликом рачунарске анализе текста. У наредном делу рада износимо завршне напомене.

\section{0. Завршне напомене}

Истраживање изнето у овом раду, део је ширег интердисциплинарног поља проучавања дискурса, или специфичније, дискурса дигиталних музеја дигиталне уметности. Један од циљева истраживања био је и испитивање различитих видова језичких израза који се манифестују у текстовима дигиталних музеја дигиталне уметности.

Пошто смо дефинисали истраживачку перспективу, описали корпус и делимитирали кључне појмове, анализирали смо шест корпуса који сачињавају текстови на веб страницама дигиталних музеја дигиталне уметности. Фокус се затим померио на разматрање резултата добијених применом рачунарске анализе текста на корпус дискурса музеја дигиталне уметности. Анализирали смо и објашњавали централне и статистички релевантне лексичке јединице повезујући их, путем илустрације, са дискурсним праксама музеја дигиталне уметности. Анализирали смо и различите лексичке групе или скупине којима смо обухватили различите колокације, синтагме, сложенице, именичке низове и различите ентитете који се различито класификују у лингвистичкој литератури.

Наша полазна хипотеза је била да високо фреквентне пуне речи овог дискурса представљају суштинске идеје које се односе на дигиталне музеје дигиталне уметности. Имајући то у виду, применио сам рачунарску анализу текста на одабране веб странице које садрже релевантне делове дискурса који се разматрају. Посматране су високофреквентне пуне речи, затим лексичке скупине, а у последњем делу рада извршена је и приказано 2Д и ЗД неметричко мултидимен- 
зионално скалирање, које, чини ми се, такође може да се користи приликом одрђивања дискурсних пракси дигиталних музеја дигиталне уметности.

Након извршене анализе, показало се да је почетна хипотеза доказана, пошто високофреквентне пуне речи присутне на веб страницама дигиталних музеја дигиталне уметности могу да представе идеје које промовишу идеологију дигиталне уметности. Такође, као што се могло видети из наведених илустративних примера, дискурс дигиталних музеја дигиталне уметности обилује лексичким јединицама и лексичким скупинама које ближе одређују предмет који се описује на веб страницама дигиталних музеја дигиталне уметности.

Наш статистички приступ показао се како корисним, тако и примењљивим за даље финије елаборације, уз коришћење доступних и поменутих алата, не пренебрегавајући и тврдње из лингвистичке литературе, по којима је могуће постулирати статистичка својства заједничка чак и свим језицима, па на основу тога утврдити и статистичке законе, па и статистичке универзалије (Kristal 1996: 86). Међутим, утврђивање статистичких универзалија за ову врсту дискурса тек је на почетку и свакако захтева даља финија, изнијансирана истраживања уз примену још већег броја рачунарских алата.

\section{Литература}

Biber, Douglas. Variation across Speech and Writing. Reprinted Cambridge: Cambridge University Press, 1995. Print.

Kristal, Dejvid. Enciklopedijski rečnik moderne lingvistike. Beograd: NOLIT, 1988. Print.

Kristal, Dejvid. Kembrička enciklopedija jezika. Beograd: NOLIT, 1996. Print.

Matthews, P. H. The Concise Oxford Dictionary of Linguistics. Reissued Edition. Oxford: Oxford University Press, 2005. Print.

Miller, Gavin et al. "The virtual museum: Interactive 3D navigation of a multimedia database", The Journal of Visualization and Computer Animation, Vol. 3, (1992): 183-197. Print.

Panciroli, Clara, Veronica Russo \& Anita Macauda. "When technology meets art: Museum paths between real and virtual." Proceedings of International and Interdisciplinary Conference IMMAGINI? Image and Imagination between Representation, 
Communication, Education and Psychology, ed. Alessandro Luigini et al., 1-14. Brixen and Basel: MDPI, 2017. Print.

Paul, Christiane. Digital Art. Revised and Expanded Edition. London: Thames \& Hudson, 2008. Print.

Proctor, Nancy. "Digital museum as platform, curator as champion, in the age of social media" Curator - The Museum Journal Vol. 53, Issue 1, (2010): 35-43. Print.

\section{Напомена о изворима примера}

Примери из корпуса коришћени у овом раду потичу из ових шест извора побројаних у следећој листи:

DAM - Digital Art Museum, http://www.dam.org/ (ексцерпирано је укупно 67 страна, 36618 речи, 26 пасуса, 3154 редова текста конвертованог у Microsoft Word 2007 формат) [приступљено 6.6.2017. године]

DiMoDA - The Digital Museum of Digital Art. A Virtual Institution, https://dimoda.art/ (ексцерпирана су два документа у Microsoft Word 2007 формату, од којих први има 18 страна, 9064 речи, 140 пасуса, 727 реда, а други има 9 страна, 999 речи, 6 пасуса, 106 реда) [приступљено 1.6.2017. године]

DBG - Dunking Bird Galleries, http://www.dunkingbirdproductions.com/pages/galleries. html (садржи 23 стране, 12.127 речи, 135 пасуса, 949 редова) [приступљено 5.6.2017. године]

LaTURBO AVEDON, https://turboavedon.com/ (10 страна, 1699 речи, 46 пасуса, 152 реда) [приступљено 5.6.2017. године]

LMNADA - Lucas Museum of Narrative Art - Digital Art, http://lucasmuseum.org/ collection/digital-art (9 страна, 581 реч, 29 пасуса, 98 реда) [приступљено 6.6.2017. године]

MOCA - Museum of Computer Art, http://moca.virtual.museum/ (2 стране, 398 речи, 17 пасуса, 50 редова). [приступљено 1.6.2017. године] 


\title{
SOME ASPECTS OF THE DISCOURSE PERTAINING TO DIGITAL MUSEUMS OF DIGITAL ART
}

\begin{abstract}
Summary
This research is part of a wider interdisciplinary field of discourse studies, more specifically, digital art museum discourse (DAMD), which explores various aspects of linguistic expressions that is manifested in digital art museum texts. The introductory part of my presentation defines the research perspective. Starting with an instance of digital art museum discourse, I go on to discuss some central and statistically relevant lexical items relating them, by way of illustration, to digital art museum discourse practices. The second part of my research is both general and specific in orientation. This part deals with the issue of corpus representativeness and describes some standard tools utilised in computational text analysis (CTA). The focus is then shifted to the discussion of the results obtained by applying CTA to the DAMD corpus. My research intention is based on the starting assumption that highly frequent content words of this discourse type might represent ideas constitutive to digital art museum discourse. To this purpose, CTA is applied to the selected Web pages containing the pertinent discourse chunks under consideration and pertaining to the discourse of digital art museums. The third part proposes an interdisciplinary approach to a theory of DAMD indicating some possible directions for further study in DAMD by means of CTA. Finally, the last part summarises my findings.
\end{abstract}

Key Words: Digital Art Museum Discourse (DAMD), the English Language, Content Words, Compounds, Discourse-Based Data, Computational Text Analysis (CTA), Computational Text Analysis Tools (CTAT). 